\title{
Exploration of Collaborative Mode of Entrepreneurship Education and Ideological and Political Education for College Students
}

\author{
Chen Diansheng \\ Wuchang Shouyi University, HuBei, WuHan, 430064
}

Keywords: entrepreneurship education; ideological and political education; collaborative mode

\begin{abstract}
The ideological and political education in colleges and universities can cultivate a group of high-quality and useful students to the society. Especially for college students today, they need to use their own consciousness to complete their studies, enter the society, and create a new industry that can promote the development of the society and inject new blood into the traditional industry. In addition, to solve the difficult employment of college students, the shallow social experience, and the problems faced by independent entrepreneurship, and to promote the public entrepreneurship, the innovation shall be conducted ${ }^{[1]}$.
\end{abstract}

With the continuous progress of China's economy and the improvement of people's living standard, the demand for material and spiritual aspects is higher and higher. At the moment, the place that can continue to output talent is still colleges and universities. The cultivation of high-quality talents should not only be confined to academic aspects, but also providing common sense and psychological support for them to go to society. Young people are the hope of the future of the motherland. The future is closely related to the mental and intellectual ability of young people. However, at present, there are more and more problems faced by teenagers in college campus life. First of all, with the increasing population, colleges and universities can only expand the enrollment, the number of college students in the country is increasing, the pressure on the current colleges and universities is gradually increasing, and the teaching effect is more discounted. Secondly, after twelve years of education, college students suddenly lost the control and did not know how to be self-disciplined and self-reliant. So it's easy to get lost in colleges and universities, and it will bring a series of negative pessimism, going astray, or getting a bad mood, or getting stuck in a net trip, or going to a crime. Therefore, the mutual union of ideological and political education and entrepreneurship education makes college students face reality earlier and change, which is very meaningful ${ }^{[2]}$.

\section{The Important Role of Ideological and Political Education and Entrepreneurship Education for College Students.}

It is still a mirror of the moon that the academic education is good, not the relationship with the society. Therefore, the ideological and political education and the entrepreneurship education for the college students are more conducive to their early thinking of their own value to the society, so that their studies can be practiced as soon as possible. In addition, it is also conducive to the promotion of innovative thinking and independence of the consciousness of college students, so that the society can reduce some of the gnawing old people, and more intelligent young people.

The ideological and political education supports the future development of college students from the intellectual aspect, and uses theory to carry out ideological and political education to college students, so that students can think about their future from the perspectives of reality and specialty, from the analysis of the practical problems to the practical problems, and then to the cultivation of innovative thinking and the reflection and summary of the problems. These are practical problems for college students, and they can also make college students better to innovate and improve their innovative thinking.

For today's college students, for all unknown things, they are full of curiosity and longing, so they are more willing to accept new things. Therefore, for the ideological and political education, it 
is more important to guide them to surpass themselves, to be confident in the future, and to arouse the courage and determination of college students to start a business. In addition, for the increasingly fierce and realistic society, many enterprises compete with each other, the fierce and cruel nature of their environment can be imagined. Therefore, ideological and political education should cultivate a good psychological quality and anti pressure ability for college students, and form a good form of teaching for students with a variety of teaching methods such as imperceptible and shallow. Good psychological quality can resist risks and enhance their sense of crisis.

Help to improve the development of cooperation between college students. For college students, professional proficiency is not only a unit for a person, but more important is to learn to cooperate fully, so that the problems encountered can be resolved as soon as possible. For a fishing boat, it is impossible for a person to complete all the tasks. Therefore, teamwork is needed. And the socialist core values in the ideological and political education are still very far-reaching for the students, not only to the integrity of friends, but also to the problem of the history of entrepreneurship, and finally can solve the problem. I think that this is the most important part of the ideological and political education, but also the most valuable part.

\section{Problems in Ideological and Political Teaching and Innovative Teaching.}

With the rapid development of Internet technology and information technology, China has gradually entered the information system, and the rise of many enterprises is closely related to the Internet. However, the Internet is a double-edged sword, which can't be beneficial to college students. The management of the network is not mature enough. Many false information, yellow gambling information and some harmful social information appear. College students are easily influenced by it and go astray. Ideological and political education can lead college students' thoughts back to normal, believing in the strength of truth and struggle, rather than eager for quick success and instant benefits, and going astray. It can also be the interaction between young people's behaviors and thoughts, and constantly go all the way, so as to complete their dreams and take fewer detours.

With the continuous updating of the times, the quality of college students is also improving, and the ability to start business is stronger and stronger. Loans for college students provide them with sufficient venture capital, and their professional knowledge and their ability improve continuously, which provide them with sufficient mental reserves. However, because college students are not deep in the world, lack of social experience, and easy to be deceived, many bad elements will make them go astray, money, pyramid marketing and so on. It is also vulnerable to the failure of entrepreneurship, becoming too negative and therefore doing nothing. At the same time, college students are also liable to be lack of responsibility and team spirit. As for paper towels, the lack of sense of morality and responsibility among college students has gradually become the problems faced by college students in the process of entrepreneurship. At this time, we need ideological and political education to provide them with experience and step by step towards entrepreneurship. So that college students can improve their overall quality in the process of entrepreneurship, so as to reduce unnecessary obstacles. Therefore, ideological and political education and entrepreneurship education are imperative[3].

\section{The Collaborative Way of Entrepreneurship Education and Ideological and Political Education}

Through the above research, it is found that college students' Ideological and political education and entrepreneurship education are inseparable. College students should be integrated into the society as soon as possible after the completion of university studies. Therefore, the ideological and political education is irreplaceable to the self idea of College Students' psychological health and entrepreneurship education. Under the cooperation, college students can become more confident in the future rather than inferiority, confusion and hesitation. This will greatly enhance the way of entrepreneurship and life for college students. Therefore, the author will propose countermeasures 
from the two major problems faced by college students, in order to solve the practical problems and mental health problems of college students.

For college students, the empty theory will not arouse any interest of college students, therefore, the ideological and political education and entrepreneurship education is not an overnight thing, the theory can play a leading role. Theory will continue to inspire and edify the aspirations and independence of college students in pursuit of entrepreneurship, so that they can take fewer detours. So that they can adapt to the trend of social change as soon as possible. And we can cultivate college students from the perspective of mental health and social experience, so that college students can become people with good psychological quality. However, those are not enough. The improvement and development of these two systems should be strengthened step by step. In addition to this, we should give priority to practice, to provide college students with the training base and the funds and venues needed for entrepreneurship, making their business more convenient, and no longer just a paper talk. For example, college student loans can provide sufficient funds and motivation for college students to start their own business. The lease site can provide sufficient space for the entrepreneurship of the University, so that the college students can get the opportunity to start a business during the University and provide the foundation for their self-confidence. In addition, colleges and universities can provide high-quality talents for college students to provide guidance for them, and provide quality guidance for college students at any time. It is beneficial for college students to rethink their sense of society and the values of the world. Thus, it is beneficial for college students to face the future in a positive attitude, and to reconsider the role and significance of Ideological and entrepreneurial education and entrepreneurship education[4].

In addition, the training of team spirit has a great effect on the lack of the sense of responsibility of the contemporary college students. On the premise of respecting the interests of the individual, we should actively advocate the development of college students in the direction of a positive energy. In the process of practice, we should not only cultivate the group consciousness of the college students, but also cultivate the college students' sense of group. The sense of group responsibility of college students should be promoted under the same value recognition and for the honor and interests of the team. We should use socialist core values to guide college students and reflect the value of values. Therefore, we should not only pay attention to the principle of insisting on justice and high quality, but also be willing to dedicate its value and ideal for the society to make a perfect end to the education of Ideological and political education.

Entrepreneurship education can promote the continuous development of Ideological and political education, and ideological and political education is the foundation of entrepreneurship education. Therefore, while promoting the innovation consciousness of college students, we should pay attention to keeping pace with the times, taking the psychological state of the contemporary college students, living habits and interests as the basis for the setting of related curriculum content. Thus, the college students will be able to face the pressure of society and life more and more, and the entrepreneurial education and ideological and political education can play a better role in the student body, the function of the two kinds of education can be effectively reacted, and then the students can improve their psychological quality and make them gradually become useful people to the society. Therefore, as for the contemporary college students, only the Internet and computer technology are used actively, and they should be combined with the development direction of the times, with the current popular teaching and research such as Taobao, Jingdong and so on. Through the analysis of their entrepreneurial model, entrepreneurial experience and innovation strategy, the deep analysis is carried out. College Students' Entrepreneurship provides experience and intellectual support. Of course, it is also possible to make a better understanding of the methods and Strategies of their own business through a deep understanding of the corporate strategies of well-known brands at home and abroad. This can not only arouse the sense of identity of college students, arouse their enthusiasm for ideological and political education, but also better get feedback and strengthen their self-confidence through factual education. In addition, for information authenticity, teachers should also alert students, and make a distinction so that students do not go astray. Then, from the perspective of socialist core values, we should carry out ideological guidance to them, so 
that they can better accept positive energy. This is the final meaning of the synergy mode of Ideological and political education and entrepreneurship education. Of course, college students should be self disciplined from themselves. They do not go astray. They are brave to say no in the face of temptation. They should learn to recognize and reject the swindlers and pyramid schemes on the rivers and lakes, and keep a common heart to face the present life, so that the eyes of the false things are not fascinated by the eyes.

In the ideological and political teaching, the employment guidance and the deep interpretation of the state situation and policy are essential. Of course, the problems faced by the college students are inseparable from the two. Therefore, the teachers should work hard in these two aspects and complete the infiltration of entrepreneurial guidance in the classroom. First, in the process of employment guidance, we should guide the entrepreneurial spirit as the foundation, and the entrepreneurial spirit includes responsibility consciousness, moral quality, political idea and team spirit. Teachers should carry out entrepreneurship education from many aspects, through the sense of responsibility, goal, scale and Entrepreneurship of the society. The plan and other aspects of the guidance and guidance to students, let college students in their own imagination of the world, can experience the difficulty of entrepreneurship and social responsibility for the same class, detailed and accurate their values, employment outlook and money outlook.

Second, in the teaching of the situation and policy, the relevant policies and regulations issued by the state in recent years for the independent entrepreneurship of the university students, the in-depth interpretation of these policies and regulations, let the college students know the advantages and disadvantages of the current entrepreneurship in our country, help to improve the ability of college students to face risk after the future. In addition, college students can also make a comprehensive judgment based on the current international situation. China is in a tense or cooperative relationship with North America, South America, the Middle East, Europe and so on, in order to face the international situation in the future and not be panicked.

Third, we should infiltrate the concept of entrepreneurship education in the process of Ideological and political education. To enable students to better have the ideological and moral quality of a entrepreneurial talent, master the necessary knowledge of entrepreneurship, so as to move towards a path of talent based on science and technology, hardship and autonomy. In order to improve the consciousness of independence and innovation of college students, the task of Ideological and political education is inevitable. It is not only the innovation and development of traditional industry and new industry, but also the thinking of management idea and management order to complete the content of Ideological and political education. If an entrepreneurial person really wants to serve the people, he can win the respect of the masses [6].

\section{Conclusion}

Through the above research, a good combination of Ideological and political education and entrepreneurship education can enable college students to better solve their own problems and solve them. In addition, under the good cooperation of Ideological and political education and entrepreneurship education, the psychological quality of college students will improve, and it will become more and more confident for the future. At the same time, with the help of schools, college students can start their own businesses to improve their social practice ability and risk tolerance ability. It can not only effectively guide the healthy growth of college students, but also serve as a good foundation for training socialist successors. Finally, we hope that ideological and political education and entrepreneurship education can be better and better in collaborative mode.

\section{References}

[1] Zhang S, Marxism S O, University S J. On the Problems and Countermeasures of College Students' Ideological and Political Education under the New Situation[J]. Guide of Science \& Education, 2017. 
[2] Fan Y C. Entrepreneurship of College Students' Ideological and Political Education from the Education Innovation Research[J]. Journal of Hubei Correspondence University, 2017.

[3] Meng Y Q. Exploration of Ideological and Political Education of College Students from the Perspective of People's View[J]. Journal of Hubei Polytechnic Institute, 2017.

[4] Zhang Z, Colleg A N. Path Analysis on the Ideological and Political Education for College Students based on the Pattern of Parent-school Cooperative Modes[J]. Journal of Hubei Correspondence University, 2017.

[5] Guo C, Wang X. Exploration on the New Mode of Ideological and Political Education Based on Hadoop Technology[J]. Science Education Article Collects, 2017.

[6] Cheng S B. Exploration of Methods for Information-based Ideological and Political Education of College Students[J]. Beijing Youth Research, 2016. 